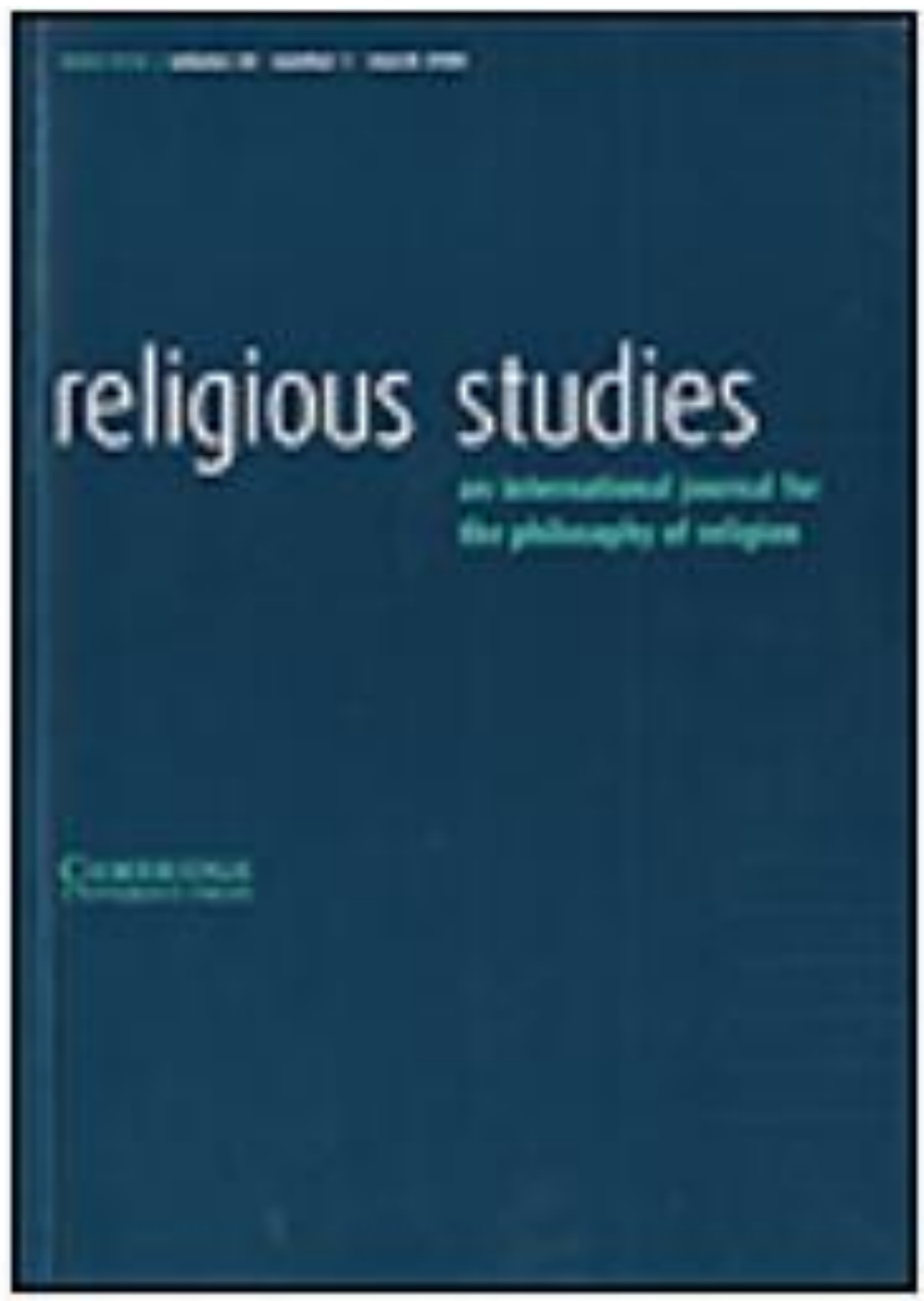

D'Costa, Gavin. "The Impossibility of a Pluralist View of Religions." Religious Studies, vol. 32, no. 2, 1996, pp. 223-232. JSTOR, www.jstor.org/stable/20019811.

Gavin D'Costa is professor of Catholic theology at the University of Bristol. For more information, see: https://berkleycenter.georgetown.edu/people/gavin-d-costa. 


\section{THE IMPOSSIBILITY OF A PLURALIST VIEW OF RELIGIONS}

This paper could be an act of public self-humiliation as in what follows I am going to suggest that a typology that I have promoted and defended against critics I now come to recognize as redundant. It has of course been previously suggested by a number of thinkers that this typology is redundant, but I can still be content that I would defend the typology against their various and different criticisms. ${ }^{1}$ However, I am increasingly convinced that the logical impossibility of a pluralist view of religions means that the typology of exclusivism, inclusivism and pluralism as three approaches or paradigms regarding Christianity's view of other religions is untenable. First, I will briefly sketch the genesis of these paradigms.

In 1983 Alan Race coined the threefold typology in his book Christians and Religious Pluralism. ${ }^{2}$ In 1986 I, amongst others, followed suit and since then the three-fold typology is found in many works dealing with Christian theology and religious pluralism. (Blame for the faulty typology therefore does not entirely rest on my shoulders.) While these definitions have been employed for examining various Christian attitudes to other religions, they have also been used as logical types to analyse other religions' attitudes to religious pluralism. ${ }^{3}$ This indicates that while the typology was developed to analyse Christian attitudes to other religions, it could equally be applied to say Hindu views of Christianity and so on. Hence, my concerns lie with the logical form of the typology. The demarcations between the three positions of exclusivism, pluralism and inclusivism are as follows. On the one extreme of the spectrum there is exclusivism. This type is defined as holding that only one single revelation is true or one single religion is true and all other 'revelations' or 'religions' are false. Here truth, revelation and salvation are

\footnotetext{
${ }^{1}$ See Ian Markham, 'Creating Options: Shattering the Exclusivist, Inclusivist, and Pluralist Paradigm', Naw Blackfriars, Lxxıv, 867 (1993), 33-41; Ken Surin, 'A Politics of Speech', in G. D'Costa (ed.), Christian Uniqueness Recontidered (New York: Orbis, 1990), pp. 192-212; J. DiNoia, The Diversity of Religions (Washington, DC: The Catholic University of America Press, 1992); S. Ogden, Is There Only One True Religion or Are there Many? (Texas: SMU, 1992). I have briefly responded to these critics in 'Christian Theology and Other Faiths', in P. Byrne and L. Houlden (eds), Compurion Encyelopedia of Thrology (London: Routledge, 1995).

${ }^{2}$ London: SCM, 1983; 2nd ed., 1994 - and Race sees no reason to question the typology in the second edition.

${ }^{3}$ See Harold Coward, Plaralism: Challenge to World Religians (New York: Orbis, 1985); Paul Griffiths (ed.), Christianity through Naw-Christian Eyes (New York: Orbis, 19go).
} 
tightly and explieitly connected. It will, in its most strict logical form, mean that for example, all those who are not Southern Baptists will be lost to the fires of hell. ${ }^{4}$ In various softer versions, it will allow for possibilities such as a post-mortem confrontation with Christ which gives everyone the chance to choose for or against the truth so as to allow to all the possibility of salvation." $\mathrm{Or}_{\mathrm{y}}$ in Buddhist and Hindu versions, in person in a future life will have the opportunity to come to liberation. Such softer versions still keep the basic exclusivist insight intact: that fundamentally only one single revelation or one single religion is true and all other 'revelations' or religions are false.

On the opposite side of the spectrum of opinions is pluralism. This type is defined as holding that all the major religions have true revelations in part, while no single revelation or religion can claim final and definitive truth. Here again truth, revelation and salvation are closely connected. This means that all religions are viewed as more or less equally true and more or less equally valid paths to salvation. The advantage of this position, argue its supporters, is that it renders genuine respect and autonomy to the various different religions. There are no adherents to this position that I know of who imply uncritical endorsement of every phenomenon that might present itself as religious; Jim Jones and his (ex) followers or the more recent Waco incident being cases in point. Pluralists usually criticize exclusivists of their own traditions on two major grounds: that they cannot deny the evidence of good, holy and loving people in other religions; and that cxclusivists have incorrect readings of their own sacred texts which misguidedly lead them to exclusivism. The order in which these criticisms are developed is sometimes reversible:

In the middle of the spectrum are those called inclusivists who, as often the case with those in the middle, try and have it both ways. They are committed to claiming that one revelation or religion (sometimes in a specific denominational form) is the only one true and definitive one, but that truth and therefore salvation can be found in various fragmentary and incomplete forms within other religions and their different claims. It is always the case that such different and sometimes rival claims are judged by the criteria arising from the one true revelation or religion, so that alternative religions and revelations can only be decmed truthful in so much as they do not contradict the normative revelation or religion and in lact must conform to it. The usual implication of this position is that Christianity is regarded as the fulfilment of other religions. Or, if we take a particular form of Hinduism, that Advaita Vedanta is considered the fulfilment of all other religions.

There ate importan wariations within all these types but as I have noted,

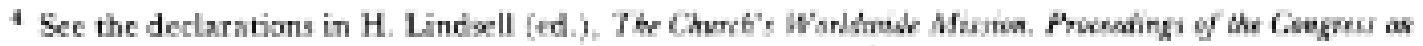

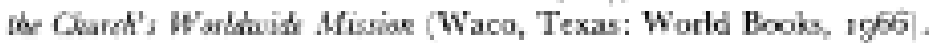

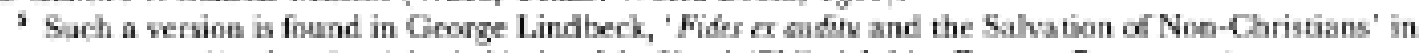

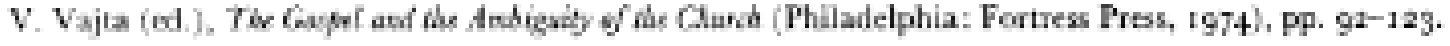


the typology is still employed in much of the discusion in this ficld. In what follows I want to argue that pluralism must aluoys logically be a form of exclusicism and that nothing called pluralism really exists. If I am right then the typologies so presented above are both false and misleading as they do not really focus on the important questions that are at stake when theologians and philosophers of religion argue about the status of other religions in regard to Christianity. And the important questions, I want to suggest, come to the foreground in this conceptual spring cleaning exercise. To preview the conclusion slightly, I shall be indicating that the important questions revolve around the justification and clarification of the various truth claims being made and the examination of how they relate to other truth claims. One main purpose of this paper is to show that there is no high ground in the pluralist position for in principle its logic is no different from the exclusivist position. The only difference is in terms of truth claims and the criteria for truth employed by the practitioners.

Before proceeding with my argument that pluralism must always logically be a form of exclusivism and that nothing called pluralism really exists, I must also register three important qualifications. First, I am going to generalize from the particular. This is inevitable and given that $I$ am claiming that there is a logical point at stake all I need are some examples. I would challenge readers to produce pluralist texts which disprove the logical point I'm trying to establish. Second, while most of my materials are extracted from the debate between Christians concerned with other religions, I would venture that the same logical point would hold true of Jewish, Muslim, Hindu and Buddhist pluralists. This would of course have to be shown and argued for from the various texts. ${ }^{6}$ Third, I can imagine that some will wish to argue that both pluralism and exclusivism are only sub-types of inclusivism rather than, as I am suggesting, that both pluralism and inclusivism are subtypes of exclusivism. However, I'm going to support the latter for it seems to me that it is in fact the logic of exclusivism that best explains the way in which the other two positions work: i.e. there are certain claims to truth and those other claims that do not conform to these initial claims, explicitly or implicitly, are false. However, in what follows I shall stay with the basic point of denying the possibility of pluralism as a logically coherent possibility as in itself it offers some illumination in examining issues raised by religious pluralism.

Here then are the steps of my argument that will be tested out against two representative pluralists. I want to suggest that there is no such thing as pluratism because all pluralists are committed to holding some form of truth

- Examples of woll plaralist texe that could be so andyod can be found in Johe Hick and Hawn

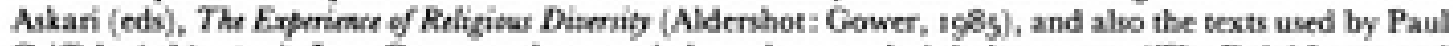
Grifiths (ed.) of aí. Jane Compon does precisely wuch an analyis in her paper: "The Dalai Lama and the World Religions: A Falue Friend?", see pp. $271-272$ of this valume. 
criteria and by virtuc of this, anything that falls foul of such criteria is excluded from counting as truth (in doctrine and in practice). Thus, pluralism operates within the same logical structure of exclusivism and in this respect pluralism can never really affirm the genuine autonomous value of religious pluralism for, like exclusivism, it can only do so by tradition specific criteria for truth. If any pluralist were to claim that they did not operate with any such exclusive criteria, they would be unable to distinguish between any two claims to revelation or truth such as that between the claims of the Confessing Church and those of the German Christians following Hitler. Such a pluralism would therefore be entirely unable to distinguish between true and false claims to revelation. It is very difficult to find a pluralist who would go to this extreme, so I shall not consider such a position. Hence, in the use of truth criteria, the pluralist by virtue of the act of exclusion of Jim Jones or the Nazis, can thereby include various other doctrines and practices in so much as they do not contradict their own basic truth claims and in this act of inclusion and exclusion such pluralisis are logically no different from exclusivists who simply argue that those who properly relate to the true revelation are included in salvation and those who do not are excluded. By noticing this logical shape, our attention is drawn to the more interesting question as to what precisely are these criteria, how are they justified, and in what fashion do they work? Hence, the real differences between those called pluralists, inclusivists and exclusivists are not, for example, that salvation may be attained by one who is a Muslim in this life (on this they may all agree), or that certain forms of loving one's neighbour are to be valued (on this too they may all agree), but rather they disagree in what counts as normative truth and how it operates, In this respect a criteriological typology to analyse different approaches to religious pluralism would perhaps be a more adequate and helpful typology and isolate the questions of revelation and truth as the most fundamental from a Christian point of view, but that clearly is for another occasion. Hence, logically speaking the pluralist is in fact no different from the exclusivist, except in the criteria employed for what counts as truth. Within Christianity this may eventually lead to the interesting claim that criteriologically, latter day pluralists differ from latter day exclusivists in that pluralists cannot properly be regarded as Christian, but that too, is for another day.

So back to the main argument. In what follows I want to isolate two different forms of pluralism from the many that exist and show how each falls into the logical type of exclusivism rather than the self-confessed pluralism of the writers concerned, a self-description also uncritically held by many observers of the debate (such as me - at one time). The two types (that are often indistinguishable and overlapping in the works of various writers) will be drawn with one particular representative for each. The two types of pluralimm that I will deal with are philosophical pluralism (John Hick) and 
practical or pragmatic pluralism (Paul Knitter). ${ }^{7}$ I will argue that these thinkers are exclusivists not pluralists.

John Hick will be my representative philosophical pluralist. Hick holds that all religions are paths to the 'Real' (a neutral term, compared to 'God' which has theistic implications or 'Nirguna Brahman' which has non-theistic implications, ctc.). This, according to Hick, is the best hypothesis which explains religious pluralism positively. He argues that the other possibilities are either saying that all religions are false, or claiming that truth resides only in a single religion with the further possibility that fragments of this truth are found in other religions which are thereby always viewed as inferior and inadequate. The most plausible hypothesis which does justice to the wide range of religions is that the Real is thought of as finally beyond all description, and certainly not exhausted in the differing descriptions given to the Real by the various religions; all of which are true to some extent and false in other ways. How are they true and how are they false? 'They are true in so much as they align believers correctly towards the Real producing an attitude of loving compassion towards one's neighbour and social and natural environment thereby breaking down the egocentricism of the believer's life. Hick argues that this phenomenon is actually found universally within the best examples of the world religions. They are false in so much as they claim ultimacy and finality regarding their conceptions of God, or Brahman, and so on and in the way they sometimes give ontological uniqueness and ultimacy to the way in which this truth is mediated.

Two device are employed to shore up this position. One is a Kantian type distinction between the noumenal and phenomenal. The Real an sich, in itself, is the noumenal which is beyond all description and the differing images within the religions are like phenomenal representations of the noumenal. In this way, such pluralists claim that the Real is beyond, but related to, conceptions such as Allah, God the Father, Nirvana, and so on. The second device is the employment of the distinction between mythic and factual truth which is used to distinguish the proper status of claims for finality and ultimacy; i.e. that they are in fact provisional and partial " For example, claims that God is diselosed in Jesus uniquely and exclusively are deemed mythical, apparently better understood as expressing the ultimate concern the worshipper has in relation to Jesus than any metaphysical daims concerning the person of Jesus." What I must now do to establish my case

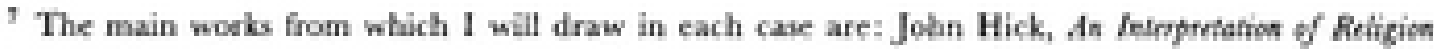

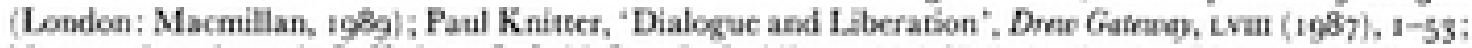

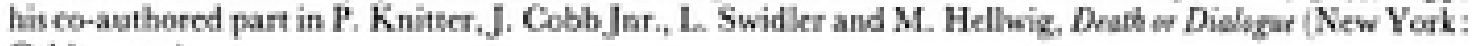
Orbin, rggo).

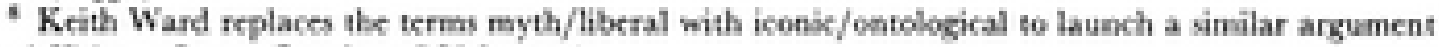
in A Vine of Furier [London: SCM, iggr)

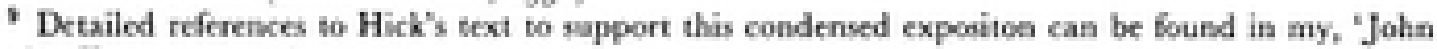

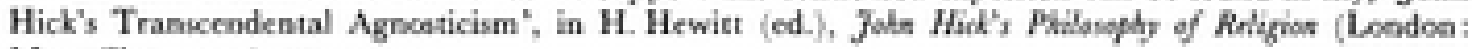

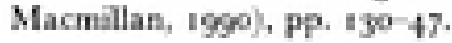


that pluralism must always logically be a form of exclusivism and that nothing called pluralism really exists is to show that this position of philosophical pluralism in fact involves specific and exclusive truth claims with specific and exclusive criteria for truth. In this respect it will be seen to grant no autonomous pluralist validity to the differing religions. To find out John Hick's truth criteria we will have to follow two differing paths. This is because there is an ambiguity as to how Hick would answer this question and textually there are two distinct answers.

One possible answer is that Hick's truth eriteria are finally theistic, grounded in a philosophical cum cross revelatory coneption of an all loving God who desires the salvation of all men and women and who creates the world so that this scenario is achieved, with the final result of eternal loving fellowship. Ultimately, claims that contradict this series of truth claims are deemed to be false and provisional. The question of the grounding of such claims cannot be pursued now, but it highlights that this question then becomes more interesting and central in the discussion. This theistic answer is certainly the one found in works such as God and the Unierse of Failhs (1973), and in the eventual eschatological scenario put forth in Death and Etemal Life $(1976)$ and in parts of An Inlerprtalion of Religion (1989). ${ }^{10}$ The reason why this answer is found is becase Hick is (and always has been) committed to defending the cognitive status of religious language and this runs directly against his pluralist aim to allow for conflicting and differing views of truth. I have noted that Hick's texts are capable of another answer to which I shall now briefly turn, but my main point stands in regard to the first answer: there are finally exclusive and particular criteria for truth and that Hick is eventually committed to excluding or mythologizing such claims that are in conflict with this truth. Concomitantly, he is found to exclude such error from salvation and his para-cschatological scenario in Death and Elomal Life is similar to exclusivists who posit a post-mortem confrontation with Christ to allow that all people will have the opportunity to attain salvation.

The second answer leads us to what I shall call transcendental agnosticism (making a claim that one cannot know what the truth is, except that there is a truth that is beyond us). This is the dominant position found in $A n$ Interpretation of Religion. Hick's distinction between the noumenal and phenomenal is such that Hick is driven to say that no one image of the noumenal is privileged which then means that the statement that the Real is all loving and desires the salvation and well being of all persons and draws them into communion with itself cannot be said to be truer than the statement that finally the Real is no different from the ultimate reality of all persons and the ultimate state consists in pure consciousness, without distinction and difference. If neither is truer and more accurate and appropriate, then either one of three consequences follow.

17 Repectively London: Marmillan: London: Collin; London: Marnillas. 
Firstly, the Real contains contradictions for contradictory things may be said of it. This is unacceptable to Hick, for the Real cannot be contradictory. Secondly, the statements can be reconciled in a higher propositional synthesis which is able to render the partial truth of both statements in such a way that their contradictory nature is overcome. In this case the resulting statement must itself be more accurate and appropriate than the two previous statemens. Hence, this synthetic statement has more appropriateness and validity about the Real than the previous two. If this is the case, then some phenomenal descriptions are privileged and more appropriate and more truthful and this was the case in the reading suggested above where Hick's incipient theism leaks out. Whatever is said on that issue, the point would be that truth criteria would emerge in the privileging of some phenomenal images as compared to others and my case would then stand. Or, thirdly, the two initial statements have no cognitive purchase at all but are only useful in creating attitudes and dispositions which lead to salvation. "This position overlaps with what I have called practical pluralism in finally affirming that the criterion of truth is a certain form of practice, not particularly associated with or justified by any doctrine or theory. In terms of ontological claims it leads to transcendental agnosticism. It is with the latter that I am presently concerned. I shall turn to practical pluralism shortly.

Now, this position of Hick's (regardless of its intelligibility) is faced with the question: but how does John Hick know that the Real is beyond all language, incapable of any description? How does he know that when claims that the Real itself chooses to reveal itself in this world, these claims cannot be taken seriously? It would take a long time to answer such questions, and Hick's Kantian Enlightenment heritage is certainly a clue in knowing where to look for possible answers. But the main point that I need to establish has been shown: transcendental agnosticism has very specific truth claims that are also exclusive truth claims. For example, it is claimed that the Real cannot be known in itself and when any religion claims that the Real has revealed itself, then such claims are false. Such pluralism cannot tolerate alternative claims and is forced to deem them as mythical. The irony about tolerant pluralism is that it is eventually intolerant towards most forms of or thodox religious belief, Christian or otherwise. Hence, whichever way Hick turns to answer the question, his answer reveals that he is an exclusivist and not a pluralist as he claims. I hope I have shown in this case that pluralism must always logically be a form of exclusivism and that nothing called pluralism really exists.

Both in its self-description and in its labelling as 'pluralism', there is a logical category mistake for the logical structure of pluralism is no different from exclusivism. Now I shall turn to the second form of pluralism : practical or pragmatic pluralism to show how the same logic operates despite some important differences. One can see that Hick's transcendental agnosticism 
also has as its counterpart a pragmatic criterion for truth: that religions are true in so much as they cause people to turn away from self-centredness to Reality-centredness, from selfish egoism to loving communion and compassion. Hick leaves off where practical pluralism begins, and it is Paul Knitter's liberation theology of religions which starts with the contention that only where there is practical socio-economic, cultural, psychological and spiritual liberation can we subsequently say that the Divine is present. ${ }^{\text {" Knitter }}$ argues that all religions are to be judged as to their truthfulness in so far as they promote the process of liberation, a process which Christians call 'the kingdom'. Knitter recognizes that he is using Christian terms, understood in the light of liberation theology, but he is confident that the reality denoted by the kingdom is not an exclusive Christian possession or derived from Christ or God. The kingdom is a life style characterized by justice, peace and goodness in both personal relations and socio-economic structures. Hence, when religions promote justice, peace and goodness we can say that the Divine is found within them. Christians call this process the 'kingdom of God'. Buddhists may call it following the dharma, and Muslims may call it submitting to the will of Allah, and so on. Of course, the opposite is also the case, so that Knitter argues that when, for example, religions promote the oppression of women in whatever way, they are to be judged as being against the kingdom. And the list can be extended regarding the poor, the outcasts, orphans, and so on. Hence, no religion is better than any other except by these ethical criteria, and under these criteria they are all in need of reform and mutual help.

Once again, for my thesis all I need to show is that Knitter's alleged pluralism is in fact working with very specific and exclusive truth claims and truth criteria to establish my point that pluralism must always logically be a form of exclusivism and that nothing called pluralism really exists. To establish this I will argue that Knitter operates with a false understanding of the relation between theory and practice so that it is both problematic to isolate values such as justice and peace apart from their tradition specific understandings; and relatedly, the notion that these particular values (in their abstractness) should to be prioritized in this way in fact severely undermines the possibility of using these criteria to establish that all religions have an equal claim to truth. Hence, it will be seen that Knitter's apparent pluralism is logically of an exclusivist type and that the real focus of interest should be regarding his criteria, their justification and their application. A criteriological typology, as I have been suggesting would help bring this important question into proper focus.

So to my criticism. Truth for Knitter is found in certain forms of social

31 For detailed references to Kaitter's texts to suppoet this condensed exposition see my 'A Response 6o Cardinal Tonko: the Kingdoen and a 'Trisitarian Exclesiology. An Analysis of Soteriocentriciam', in

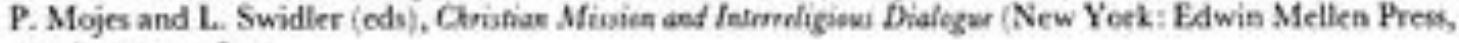
1991), pp. 51-61. 
action such as justice, peace and goodness which can possibly be found in all religions and does not prioritize any religion or that religion's tradition specific understanding of the Divine. Here at last, it is claimed, there is the ability to affirm genuine plurality. Now practical pluralists are ironically oddly abstract about such values, and Knitter seems to be only vaguely aware of the thees of MacIntyre and Hauerwas, for example, who argue that all ethics are tradition specific narrative forms of reflection and practice. Hence, there is no such concept and practice as 'justice' without the narrative tradition that defines it and specifies the conditions for pursuing it, and the types of agents that may or may not engage in the pursuit of justice, and the way in which it may relate to other concepts and practices within that narrative. "2 Put bluntly, one may ask Knitter, "Whose justice, and which peace?' is he intending. One religion's justice may be another's malpractice. Some examples should suffice to make it clear that $\mathbf{K}$ nitter's vague injunctions implicitly contain highly ramified theoretical accounts which are somewhat hidden from sight, including the theoretical claim of the priority of practice. Consider, for example, the way in which dietary laws in orthodox Judaism may prohibit "sharing food 'with non-Jews and the way in which this may conflict with the notion of "sharing food" in everyday life for at Christian, but also the way in which "sharing food" operates in the love feast of Christian communities which will often contain various restrictions, specially regarding those outside the particular Christian community. Or consider the way in which Roman Catholies exclude women from the "priesthood" and the way that Anglicans do not share this view of "priesthood' so that the question concerning the oppression of women is not at all, at one level, applicable to the Roman Catholic teaching, unles one has decided, on Roman Catholic grounds, that it is contrary to the truth of the gospel and tradition. Or, to stay with women, consider the notion of justice in the abortion debate where it is regarded by some as just that a woman has a right over her own body in contrast to the view that it is just to protect the rights of the unborn foetus, be it male or female. All this simply indicates that justice, peace and the good cannot form the wide neutral pluralist platform on which to unite religions, for it contains (in this case admittedly obscure) truth claims and criteria which will exclude as well as include. It should also be noted that even within Christianity, Knitter's Pelagian-type proposals would face severe theological questioning for they presuppose a very clear causal relation between human action and divine action. Hence, there would have to be a highly specific form of theological reasoning required to substantiate the thrust of Knitter's argument and this again would locate him properly in the logical category of exclusivism.

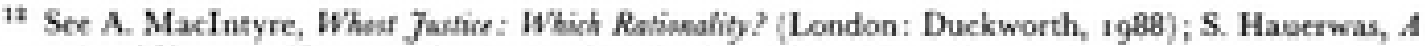

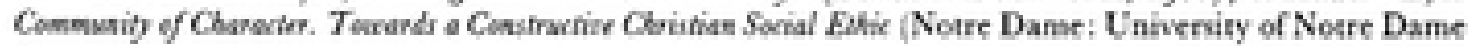
Fres, [g\$1].
} 
In conclusion, Knitter is committed to a doctrine of 'God' or the Divine which entails certain social actions and sustaining beliefs and presuppositions, which in turn exclude other forms of social actions and their sustaining beliefs. In this respect, the pluralist is surely, and can only be, an exclusivist!

I would suggest that the same logic will be found in other versions of pluralism. Hence, in Huston Smith's or Seyyed Hossein Nasr's 'perennial philosophy' or esoteric pluralism one discovers the basic truth claim presupposed is that of a mystical non-dual philosophy of unity; or in the Hindu thinker, Sarvapelli Radhakrishnan's mystical unity of religions thesis we find the philosophical underpinning of Advaita Vedanta's non-dual truth being affirmed and it is this truth that controls the alleged pluralism of Radhakrishnan; or in the Dalai Lama's tolerant pluralism we find traditional Tibetan Buddhist doctrine being exclusively affirmed and grounding the apparent pluralism. ${ }^{13}$. The general point 1 have been trying to make is that pluralism as a category simply does not exist, only another form of exclusivism. What is interesting and important, and herein lies the question that I have been trying to recover, is what notion of exclusive truth is being employed, what is its basis, and what are its effects? The pluralism, inclusi= vism and exclusivism typologies have often skewed the question so that it is a matter of how many are saved. Ironically, it also fails properly to answer that question as in fact one can find universalists in all three camps. What my criticisms may have achieved is to point to different questions that are generated when the typology breaks down; and that is the question (within Christianity): what is revelation, in what way do we come to know it and how do we relate it to other truth claims that we encounter? ${ }^{14}$ The logical form of this question I believe to be applicable more widely if one were to consider other religions, but again that is for another day. In conclusion the differentiation between pluralism and exclusivism does not really seem to make an objective distinction, except in so much as it indicates that usually those called pluralists are exclusivists without knowing it, they are (as latter day inclusivists might say) anonymous exclusivists! ${ }^{15}$

Department of Theology and Religious Studes, Uniuersily of Britol, 36 Tydalls Park Road, Bristol BSP , $P L$

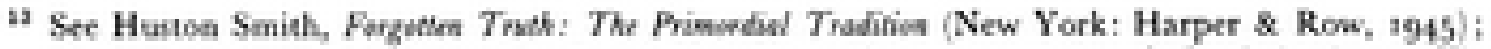

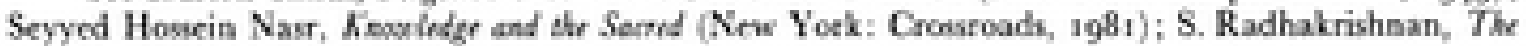

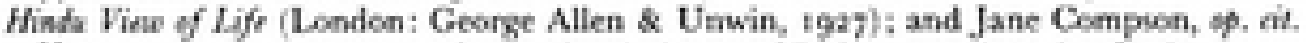

it See my "Revelation and Revelations", Modm Tholug, $x_{4} 2$ (1904) ibs-85.

\$I am gratulu go Prolewor Paul Helm of King's College London for inviting me to present a verion

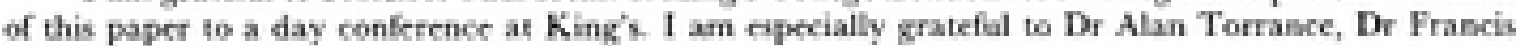

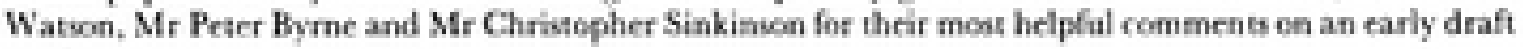
verrion.
} 